\title{
COVID 19 IMPACT ON FOOD CROP AGRICULTURE IN EAST JAVA INDONESIA
}

\author{
${ }^{1}$ Nugrahini Susantinah Wisnujati, ${ }^{2}$ Endang Noerhartati \\ ${ }^{1}$ Departement Magister Of Agribussines Universitas Wijaya Kusuma Surabaya, ${ }^{2}$ Departement Of \\ Agroindustrial Technology Universitas Wijaya Kusuma Surabaya \\ Email : wisnujatinugrahini@uwks.ac.id, endang_noer@uwks.ac.id
}

\begin{abstract}
Purpose: The purpose of this study is to analysis the impact of covid 19 on food crop agriculture in East Java Indonesia.

Design/methodology/approach: The research sample was an agricultural extension, and each region was by two (2) people chose, the reason for selecting agricultural extension was because the farming instructor accompanied farmers and had data on product development and farmer's behavior before COVID 19 and after COVID 19. Interviews were held from March to April 2020. Besides using primary data, this study also uses secondary data from the Central Statistics Agency (BPS Indonesia) from 1993 to 2015 and data from FAO from 1993 to 2015.

Findings: The occurrence of COVID 19 has an impact on all aspects of the world and all sectors, one of which is food crops, how the effects of COVID 19 on food crop agriculture in East Java, the results of the study are the behavior of farmers in East Java relatively no difference before the occurrence of COVID 19 and after COVID 19, farmers still work as usual. Rice supply at the level of the farmer community is still sufficient because farmers have harvested a month in March 2020. In Bangkalan Madura the village government has the policy to carry out the harvest by renting harvest tools to anticipate COVID 19, while in Gresik and Lamongan areas farmers continue to do the harvest without assistance harvester. The role of advisory counselors is needed by farmers, this is because extension agents can become counselors of the COVID 19 problem in the community during a pandemic like this. With the COVID 19 outbreak, the brothers of the farmers returned home because of the culture of going back or also because the factories, shops, restaurants where they work have been close, this is a burden for farmers.
\end{abstract}

Research limitations/implications: Number of informant is small.

Practical implications: Agricultural management constraints in East Java, the majority of farmers are small farmers, institutions at the level of farmers are weak, limited access to markets and credit, inadequate infrastructure, have constrained agricultural productivity growth of small farmers. So, the condition must be improved.

Originality/value: The condition is specific in Bangkalan.

Paper type: Research paper.

Keyword: COVID 19, food crop, food Management

Received: July $21^{\text {st }}, 2020$

Revised: September $16^{\text {th }}, 2020$

Published: September $30^{\text {th }}, 2020$

\section{INTRODUCTION}

Agriculture in Indonesia, one of which is food crop agriculture, food crops are dominated by rice and corn products. Rice and corn are food crops that are potentially consumed by the people of Indonesia, in research Zaeroni \& Rustariyuni (2016) state that rice is the staple food of Indonesian people. Indonesia, 
which was previously known as the most significant food-producing country in the world, is currently experiencing a shift, where Indonesia's rice production has decreased compared to China.

Data from FAO 2020 shows that Indonesia produced 122,203,873 tons of rice, compared with Chinese production, which was able to reach $366,985,482$ tons, which that Indonesia's rice production was only 32.3 percent. Compared to Chinese manufacturing, however, in 2001 to By 2018. There was a shift in data, where Indonesia was superior compared to other ASEAN countries namely Thailand and Vietnam, the average rice production in Thailand and Vietnam in 2000 up to 2018 was 60,298,396 tonnes and Vietnam $75,035,896$ tonnes, this matter showed that Thai production was only 49.3 percent compared to Indonesia and Vietnam's output was 61.4 percent compared to Indonesian production.

Maize production in China is still superior to Indonesia, which is $348,228,559$ tonnes, compared to Indonesian corn production 32,385,863 tons with corn producers in China, Thailand and Vietnam's production of 8,640,353 and 8,150,087 tonnes, meaning that Thailand's corn production is 26.7 percent compared to Indonesian Corn production and Vietnam's 25.2 percent compared to Indonesian Corn production.

The condition of Indonesia's rice and corn production in the world will have an impact on the status of rice and corn in Indonesia, especially in East Java, East Java is a region that has the potential to produce rice and corn compared to the other area in Indonesia, on the other hand, because of Indonesia's demand for rice and corn large enough.

The occurrence of COVID 19 has an impact on all aspects of the world and all sectors, one of which is food crops, how the effect of COVID 19 on food crop agriculture in East Java, this research is fascinating because Agriculture is crucial for development, mainly because agriculture can absorb the workforce of the majority (Alexandratos \& Bruinsma, 2012).

The objectives of this study are:

1. Analyzing the performance of rice and corn production in East Java, Indonesia

2. Analyzing the impact of COVID 19 on agriculture in East Java, Indonesia

\section{METHODOLOGY}

The selection of the research area was carried out deliberately in the districts of Gresik, Lamongan, and Bangkalan, while the reason for the range of the city was because the area had the potential to produce rice and corn. The research sample was an agricultural extension, and each region was by two (2) people chose, the reason for selecting agricultural extension was because the farming instructor accompanied farmers and had data on product development and farmer's behavior before COVID 19 and after COVID 19. Interviews were held from March to April 2020. Besides using primary data, this study also uses secondary data from the Central Statistics Agency (BPS Indonesia) from 1993 to 2015 and data from FAO from 1993 to 2015.

\section{RESULTS AND DISCUSSION}

\section{A. Food Crops Agriculture Performance in Indonesia}

The performance of agricultural food crops can see from the area of rice and maize production in East Java. From the results of the analysis can be presented in the city of rice farming as follows:

1. Agriculture Land Area Indonesia

The area of agricultural land in East Java shows the highest with an average area of 1,103,236 hectares, followed by Central Java 967,499 hectares and West Java 929,493 hectares, meaning that the harvest area of East Java is the most extensive compared to other regions in Java. The narrowest is the particular area of Yogyakarta, and this can see in figure 1. 


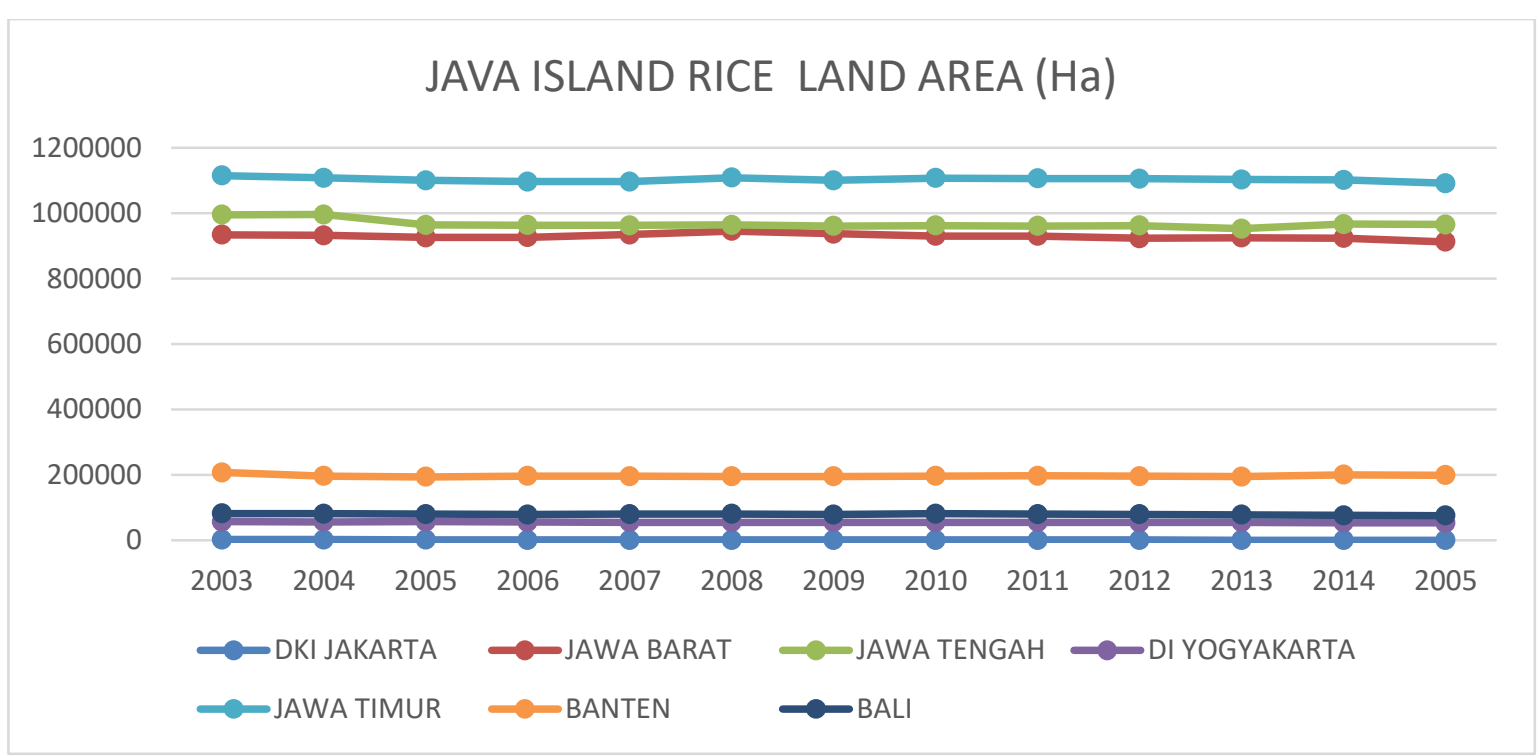

figure 1. Source : BPS Indonesia, 2020

The area of agricultural land in East Java is the most extensive, with an average area of 1,103,236 hectares, followed by Central Java 967,499 hectares and West Java 929,493 hectares, meaning that the harvest area of East Java is the most extensive compared to other regions in Java. The narrowest is the particular area of Yogyakarta, and large land can be a development capital. Therefore, there is widespread belief that secure land tenure is the key to development (Alexandratos \& Bruinsma, 2012). Unsafe land rights cause market imperfections and increase risk perceived by farmers, such as the use of lower inputs and decreased productivity (Nguyen, 2012).

2. Rice Production in Indonesia

Based on BPS Indonesia data from 1993 to 2000, shows that rice production in East Java is still lower than in West Java, and in 2001 East Java rice production was able to increase output almost the same as West Java. Indicates that broad extensive agricultural land does not mean that it will be able to produce high production. It is conveyed by Ayehu \& Besufekad (2015) that the use of agricultural land must also pay attention to topography, climate, physical and chemical soil, soil fertility, and socioeconomic conditions of the community.

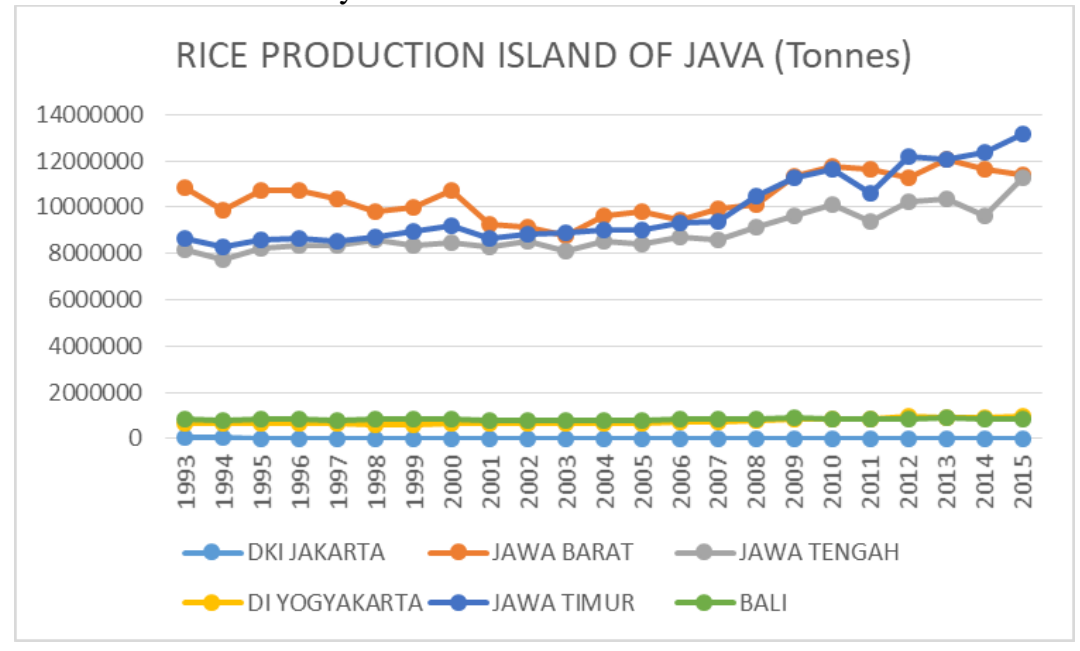

Figure 2. Source : BPS Indonesia, 2020

Rice production in East Java, West Java, and Central Java tends to increase, but the particular regions of Yogyakarta and Bali show stagnant development, this is because the Bali region is a tourism area, relatively much land is intended for tourism, as well as the Jakarta area as the capital of the State of Indonesia 


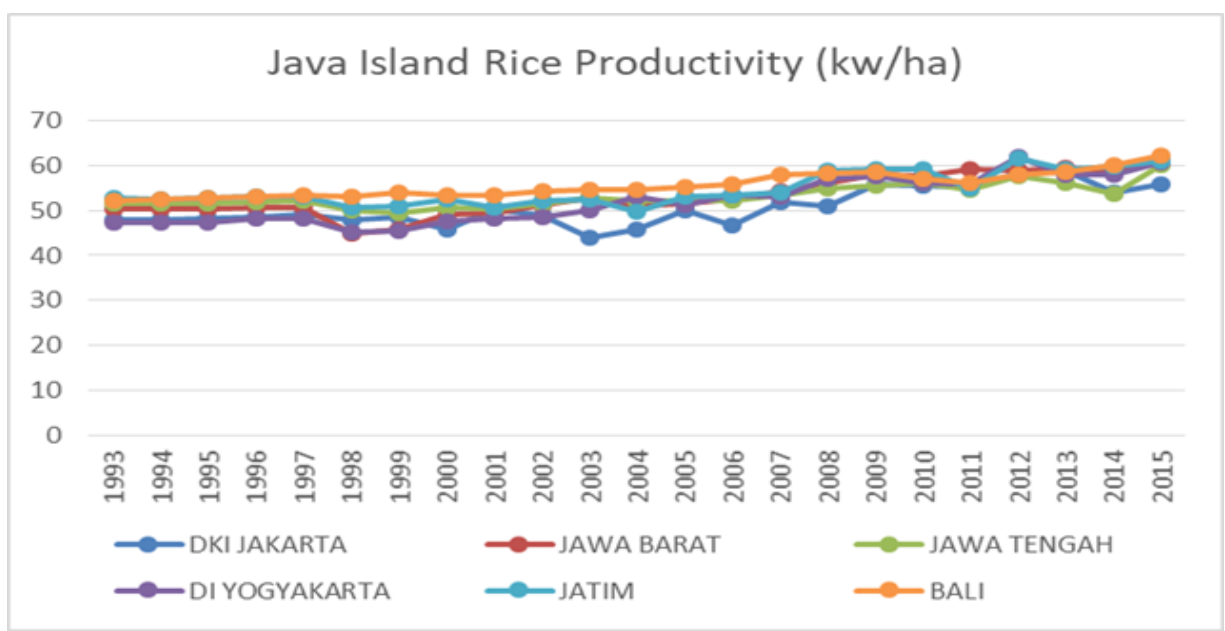

Figure 3. Source : BPS Indonesia, 2020

The area of agricultural land owned by East Java is relatively the most extensive compared to other regions in Java and Bali, but in rice productivity, the province of East Java is still lower compared to Bali. The value of Bali rice's productivity is 55.64, while the amount of East Java's rice productivity is 54.72. That shows that the use of agricultural technology in East Java still needs to be improved.

The average rice productivity in the West Java region was 53.23, and Central Java 53, 17, while the lowest productivity was Jakarta, which was 50.6.

\section{B. Impact of COVID 19 on agriculture in East Java, Indonesia}

The emergence of COVID 19 occurred in late December 2019, a previously unknown coronavirus, currently named the 2019 novel coronavirus, emerged from Wuhan, China, and caused severe outbreaks in many cities in China and expanded globally, including Thailand, the Republic of Korea, Japan, America. Countries, Philippines, Vietnam. Wu, Chen, \& Chan (2020) As of March 10, 2020, more than 100,000 people from more than 100 countries have been infected, with more than 4000 deaths reported. Clinical manifestations of COVID-19 consist of fever, cough, dyspnea, myalgia, headache, and diarrhea (3). Fatal lung involvement and multi-organ failure have occurred in some infected individuals (4) Wu et al. (2020), a challenge for all is that a significant proportion of cases that are mild or asymptomatic cannot be diagnosed and not reported.

The impact of COVID 19 in East Java discussed from two (2) aspects, namely the behavior of farmers in East Java and the economy of farmers in East Java.

Farmer's Behavior During the Occurrence of COVID 19

1. The behavior of farmers in East Java is relatively no difference before the occurrence of COVID 19, and after the COVID 19, farmers still work as usual when working in the fields, because the physical distancing has been carried out by farmers, the sunlight received and even healthy for farmers. In the home environment and farmer, communities continue to follow procedures as recommended by the village government.

2. Farmers have carried out the harvest in March 2020, In Bangkalan Madura the village government has a policy initiative to carry out the harvest by renting harvest tools to anticipate COVID 19, whereas in Gresik and Lamongan areas the harvest is still carried out by farmers without the aid of a harvester (Combine harvester)

3. Farmers have started planting rice in April and harvest of July 2020.

\section{Farmer Food Management COVID Occurrence 19}

1. The rice supply at the level of the farmer community is still sufficient because farmers have harvested in the month of March 2020. In Bangkalan Madura, the village government has the policy to carry out the harvest by renting harvest tools to anticipate COVID 19, whereas in Gresik and Lamongan areas the harvest is still carried out by farmers without the aid of a harvester

2. In the management of agriculture in East Java, the majority of farmers are small farmers, institutions at the level of weak farmers, limited access to markets and credit, inadequate infrastructure, have constrained agricultural productivity growth of small farmers.

3. Steps needed to increase the productivity of smallholders, including easy access to land, training to improve skills and encourage technology adoption and innovation, and removing barriers to trade. At 
regional and global levels, barriers to international trade need to be addressed (Salami, Kamara, \& Brixiova, 2010).

4. Farmers need the role of advisory counselors, this is because extension agents can become counselors of the COVID 19 problem in the community during a pandemic like this, and this is in line with research Adawiyah et al. (2018), that farmers' facilitators influence the adoption of technology new

5. With the COVID 19 outbreak, relatives of the farmers returned home because of the culture of going back or also because the factories, shops, restaurants where they work have been closed, this is a burden for farmers because of course, they have to take food from farm families, even though the results March harvest is used for planting costs and savings which can only last until approximately just June 2020

\section{CONCLUSION}

1. Farmers' behavior in East Java is relatively no different before the COVID 19 and after the COVID 19,

2. Supply of rice at the level of the farming community is still sufficient because farmers have harvested a month in March 2020, can last only until June 2020

3. Agricultural management constraints in East Java, the majority of farmers are small farmers, institutions at the level of farmers are weak, limited access to markets and credit, inadequate infrastructure, have constrained agricultural productivity growth of small farmers.

4. Steps are needed to increase the productivity of small farmers, including easy access to land, training to improve skills and encourage technology adoption and innovation and remove barriers to trade.

5. farmers very much needed counselor, this is because extension agents can become counselors of COVID 19 problems in the community at a time

6. With the COVID 19 outbreak, the brothers of the farmers returned home because the culture of going back became a burden for farmers because of course, they had to take food from farm families.

\section{REFERENCES}

Adawiyah, C. R., Sumardjo, N., \& Mulyani, E. S. (2018). Faktor-Faktor yang Memengaruhi Peran Komunikasi Kelompok Tani dalam Adopsi Inovasi Teknologi Upaya Khusus (Padi, Jagung, dan Kedelai) di Jawa Timur. Jurnal Agro Ekonomi, $35(2), \quad 151$. https://doi.org/10.21082/jae.v35n2.2017.151-170

Alexandratos, N., \& Bruinsma, J. (2012). World Agriculture Towards 2030/2050 (No. 12-03). Rome.

Ayehu, G. T., \& Besufekad, S. A. (2015). Land Suitability Analysis for Rice Production: A GIS Based MultiCriteria Decision Approach. American Journal of Geographic Information System, 4(3), 95-104. https://doi.org/10.5923/j.ajgis.20150403.02

Nguyen, T. T. (2012). Land Reform and Farm Production in the Northern Uplands of Vietnam*. Asian Economic Journal, 26(1), 43-61. https://doi.org/10.1111/j.1467-8381.2011.02067.x

Salami, A., Kamara, A. B., \& Brixiova, Z. (2010). Smallholder Agriculture in East Africa: Trends, Constraints and Opportunities (No. 105). Tunis.

Wu, Y.-C., Chen, C.-S., \& Chan, Y.-J. (2020). The outbreak of COVID-19. Journal of the Chinese Medical Association, 83(3), 217-220. https://doi.org/10.1097/JCMA.0000000000000270

Zaeroni, R., \& Rustariyuni, S. D. (2016). Pengaruh Produksi Beras, Konsumsi Beras Dan Cadangan Devisa Terhadap Impor Beras Di Indonesia. E-Jurnal EP Unud, 5(9), 993-1010. 